\title{
The Role of Private Sectors for Trade Liberalizatio in Connection with Export Promotion
}

\author{
Ephrem Ahadu*, Ageze Chufamo \\ Department of Civic and Ethical Studies \\ Wachemo University, Ethiopia \\ ${ }^{*}$ Corresponding author's email: Tabiney72 [AT] gmail.com
}

\begin{abstract}
In contemporary world the neoliberal economists have pursued to establish the thought that economic liberalization consistently promotes growth and decreases poverty in less developed countries. Liberalization of markets in the developing countries, according to them, promotes exports and it will create economic perfection by intensifying competition between domestic and external economic actors and exposing management and workers to improved practices Did the market liberalization policies of Ethiopia is helpful? This paper surveys the literature and provides its own assessment of the nexus between private sector and trade liberalization in connection with export promotion. The country's step wise liberalization process has shown some favourable prospects for investment and growth. However, the next steps, liberalizing the capital account and leaving the exchange rate to be determined in the market, among other things, require a skillful design. The capital account which is still left unliberalized has to wait for some time till the economy ensures a sustainable capacity of generating foreign currencies. Otherwise economic instability would follow and consequently, the reform process would be as stake.
\end{abstract}

Keywords---- Trade Liberalization, Role of Private Sector, Export Promotion

\section{INTRODUCTION}

A growing and unsustainable debt burden has become the typical characteristic of LDCs for the last two decades or so. Economis ts argue that this imbalance in the external sector is to some extent explained by the wrong policy meas ures taken so far in these countries. Structural change is vital for sustaining economic growth. In simple terms, structural change can be defined as the reallocation of labor from low-productivity sectors to more dynamic (higher-productivity) economic activities. ${ }^{1}$

Some of the policy measures which were ill-devised include: over-valued exchange rate as a means of arresting domestic inflation, import taxes as a means of protecting the domestic production of importable, and export duties, as a means of encouraging non-traditional exports. Far from attaining what they were meant for, these policy measures resulted in the proliferation of unproductive activities which are dubbed in the literature as 'rent-seeking' - the rising involvement of the private sector into unproductive venture in an attempt to extract the premium, or rent seeking, induced by the wide dis parity between controlled official and 'market clearing' prices. Ethiopia was not except ion to the perverse impact of policies mentioned above. As of 1987/88 the amount of foreign reserve available could only finance 3.4 months of imports, a level which was 11.8 months in 1974/75(ONCCP, p.53). Private sector exports declined from 68 percent of total exports in 1979 to 30 percent in 1982, which further decreased to 15 percent of the total in 1985. This is not due to the increased volume of exports by para-statal organizations but a result of increasingly declining number of exporters and/or their volume of exports. Furthermore, almost all industrial exports of the country needed subsidy by the 1980s so much so that according to a study (Minis try of Trade, 1989), in the years between 1983 and 1986, a one birr equivalent foreign exchange earning required a subsidy ranging between 0.11 birr to leather and shoe exports, and 1.46 birr to that of salt. As such, aside the far-fetched exces sive controlon the private sector, there was hardly any economic environment to the state sector so to speak. As a result of mal designed policies and other factors, the external imbalance of the country has widened from 195.8 in $1974 / 75$ to $-1,492.7$ in 1991/92, which shows a compounded rate of annual growth of 12.7 percent. The indebtedness of the country has also increased tremendously, and as such, that portion of fixed inves tment financed through foreign borrowing increased from mere 2 percent in the early 1970s to more than 80 percent in 1989/90(ONCCP, p.53). Cognizant of these problems, the transition to a market-oriented economy was initiated in 1989/90 when the military government, as a last-ditch attempt, declared the "Mixed Economic Policy". But a more comprehensive policy reformhas

\footnotetext{
${ }^{1}$ Structural change can also refer to the changing composition of output. However, since shifts in production tend to precede shifts in employment, this transformative process is arguably only under way once labor starts to relocate.
} 
only been started with the launching of the IMF-World Bank Supported Structural Adjustment Program (SAP) by the present Transitional Government.

Rectify ing policy flaws and launching a tran sition to a market oriented economy, where the priv ate sector is to play the leading role, however, needs a cautious and step-wise move. A sustainable economic environment is a necessary condition for the private sector to invest in exports. The danger associated with the state of domestic inflation and real exchange rate appreciation, are as much crucial policy concern as areas of import and export taxes. In this regard, this paper tries to address the following questions.

What do recent development in the Ethiopian economy demonstrate? Es pecially, what do the low level of inflation as well as the increased volume of imports in the first nine months since the start of the policy indicate (despite the devaluation of the birr and unchanged rates of import taxes)? Do they indicate the successfulness of the liberalization process? Or, otherwise? What steps should betaken, hereafter, especially with respect to creating a sustainable environment for private investment in the area of foreign trade?

\section{CONCEPTUAL FRAMEWORK: OVERVIEW}

\subsection{Defining Economic liberalism}

Many developing countries (DCs) have recently introduced major economic reforms. Inward-looking policies, including restrictions on the inflow of technology and direct foreign investment, protection from competing imports, over-valued exchange rates and industrial licen sing regimes, are being replaced by outward-looking, trade-oriented and market-responsive regimes $^{2}$ Economic liberalism, in the classic rather than the American sense, refers to policies that reduce government constraints on economic behavior and thereby promote economic exchange: "marketization." Political liberalism refers to policies that reduce government constraints on political behavior, promote free political exchange, and establish rights to political participation: "democratization. ' ${ }^{3}$. Economic liberalization has been central to adjustment policies introduced in developing countries since the late 1970s, mostly in the context of the conditions for lending set by international financial institutions. Thus, government policies were redirected to follow a non-interventionist, or laissez-faire, approach to economic activity, relying on mar- ket forces for the allocation of resources. It was argued that market-oriented policy reforms would spur growth and accelerate poverty reduction $(\mathrm{Vi}, 2002)$. From this perspective, government intervention in markets is seen as both inefficient and distortionary. It is argued that even if an interventionist State acts with good intentions, it does not have the competence to manage the economy well. By moving scarce resources into less productive economic activities, the State is thought to reduce overall economic growth, with adverse consequences for poverty reduction ${ }^{4}$. Researchers Matambalya \& Wolf (2001) pointed out that economic liberalization includes both stabilisation and structural adjustment . We consider liberalisation of both domestic and external sectors. It involves measures such as expenditure compression, freeing the various sectors of the economy from res trictions relating to capacity, size and pricing policy, reforms in trade, exchange rates, fiscal, monetary and labour market policies, relaxing controls on foreign in vestment, opening up the economy to competition from abroad.

As the 1980s came to a close, economic liberalis massumed a virtually uncontested position in development economics, signaling the triumph of what Hirschman called the "monoeconomics" claim. The central tenet of development economics-that late developers were vulnerable to severe market failures which presaged a large role for the state in economic planning-was thoroughly discredited. ${ }^{5}$ Etatisme, in all its guises, came under attack, and "state shrinking," privatization, and liberalization became the watch-words of a new ascendancy in development policy. In the popular realm, economic liberalization and privatization were increasingly viewed as indicia of a grand his torical teleology in which markets and democracy were triumphant. ${ }^{6}$ In scholarly discourse, where, beginning with the first critiques of modernization theory, the emphasis had been on explaining discontinuity and diversity, the new orthodoxy reasserted the uniform laws of neoclassical economic theory. ${ }^{7}$

2 Katrak, H. (2000). Economic liberalization and the vintages of machinery imports in developing countries: An empirical test for India's imports from the United Kingdom. In Oxford Development Studies (Vol. 28). https://doi.org/10.1080/713688317 3 Simmons, B., Dobbin, F., \& Garrett, G. (2007). Introduction : the diffusion of liberalization.

$4 \mathrm{Vi}, \mathrm{C}$. (2002). Economic liberalization and poverty reduction.

${ }^{5}$ Albert Hirschman, "Rise and Decline of Development Economics." in Albert Hirschman, Es says in Trespassing (New York: Cambridge University Press), pp. 1-24.

${ }^{6}$ Francis Fukuyama, The End of History and the Last Man (New York: Free Press, 1991). See also Jan S. Prybyla, "The Road from Socialis m: Why, Where, What and How," Problems of Communis m, 40 (January --A pril 1991), pp. 1-17

${ }^{7}$ See, for example, Hernando De Soto, The Other Path:The Invisible Revolution in the Third World (New York: Harper and Row, 1989); P. T. Bauer, Dissent on Development: Studies on the Debate in Development Economics (Cambridge, 
The African development policy landscape has changed radically over the last three decades. Liberalization and privatization measures aimed at opening up to global market forces and attracting private investment have replaced state intervention and public ownership, e.g. building infant industries. Ironically, while policy debates during the pre-liberalization developmental era s eriously considered the interactions between external and internal factors, the subsequent liberalization era has tended to focus almost exclusively on the 'domestic' determinants of economic performance, assuming that external market forces are benign and price perfecting, thereby carrying a strongly positive influence on economic performance and prospect ${ }^{8}$.

The policy shift dates back to 1981, when the World Bank published the influential Accelerated De- velopment in Sub-Saharan Africa: An Agenda for Action, often referred to as the Berg Report, after its principal author, Elliot Berg, from the University of Michigan's Economics Department. This report recommended adopting a more outward-oriented program of raw materials exports, eliminating subsidies and controls, and letting market forces determine the prices for raw materials exports. The international sovereign debt crises from the early 1980s provided an opportunity for the Bretton Woods institutions (BWIs) to broaden this agenda and impose it on recalcitrant governments through policy conditionalities for providing desperately needed credit.

The focus of most of the literature has been on the implications of completeliberalization despite the fact that complete trade liberalization will clearly not occur as a res ult of the Uruguay Round. Recent studies by Loo and Tower(19901, Tyers and Falvey (1989) and by Martin, Knudsen, Tsigas and van der Mensbrugghe (1991) make it clear that the consequences of partial liberalization cannot be assumed to be a simple fraction of the consequences of total liberalization ${ }^{9}$.

Bey ond the general benefit of exposure to an advanced, competitive world market, the act of trade liberalization also carries the potential of dynamic benefits. In their systematic study of industrialization and development, Chenery et al. (1986) focused on the sources of growth in total factor productiv- ity (Dornbusch, 1992). Their work suggests that periods of trade liberalization also tend to be periods where total factor productivity growth is unusually high. Harrison (1991) and Salvatore and Hatcher (1991) dis cuss supportive evidence. The 1991 World Development Report (p. 100) shows for a large group of countries a positive association between trade liberalization and the residual in GDP growth after accounting for the growth in inputs. An aggressive trade opening may well qualify as a Schumpeterian change that triggers growth. As Schumpeter wrote (1934 [1983], pp.64-66): "Development in our sense is a distinct phenomenon.... [I]t is spontaneous and discontinuous change in the channels of the flow, disturbance of equilibrium, which forever alters and displaces the equilibrium state previously existing.... Development in our sense then is defined by the carrying out of new combinations."

In Schumpeter's analysis, the discontinuity of events and opportunities is the critical ingredient in promoting a new growth environment, it is change that is the source of increased productivity. Such a discontinuity involves, specifically, the introduction of a new good; the in troduction of a new method of production; the opening of a new market; the conquest of a new source of supply of raw materials or half-manufactured goods; and the carrying out of the new organization of any industry. Together, deregulation and trade reform can s hake an economy out of a slow-growth trap, toward an acceleration of growth which then develops its own dynamics and financing. Of course, there is no basis here for a sustained increase in growth. Rather, the model suggests a temporary acceleration of growth that need not be sustained indefinitely but will have shifted the economy to a higher growth path ${ }^{10}$.

According to proponents of trade liberalization, the major reason for the rapid growth aris ing from trade liberalization is the dynamic gains from trade. The dynamic gains accrue from augmenting the availability of resources for production by increasing the quantity and productivity of resources. One of the major dynamic benefits of trade is that it widens the market for a country's pro- ducers. If production is subject to increasing returns, export growth becomes a source of continued productivity growth since there is also a close connection between increasing returns and capital accumulation. For a small country with no trade, there is very little s cope for large-scale in vestment in advanced capital equipment, and specialization is limited by the extent of the market. Other important sources of dynamic benefits from trade include: stimulus to competition, acquisition of new knowled ge and ideas and dissemination of technical knowledge, more FDI, and changes in attitudes and

Mass.: Harvard University Press, 1972); Robert Bates, Markets and States in Tropical Africa (Berkeley: University of California Press, 1981); Robert Bates, "Governments and Agricultural Markets in Africa," in Robert Bates, ed., Toward a Political Economy of Development: A Rational Choice Pers pective (Berkeley: University of California Press, 1988), pp. 331-358; Deepak Lal, The Poverty of Development Economics; Bela Balas sa et al., "Toward Renewed Growth in Latin America" (Was hington, D.C.: Institute for International Economics, 1986).

${ }^{8}$ Jomo, K. S., \& Von Arnim, R. (2012). Economic Liberalization and Constraints to Development in Sub-Saharan Africa. Good Growth and Governance in Africa: Rethinking Development Strategies, (67). https://doi.org/10.1093/acprof:oso/9780199698561.003.0017

${ }^{9}$ Brandaõ, A.S. P., \& Martin, W. J. (1993). Implications of agricultural trade liberalization for the developing countries. In AgriculturalEconomics (Vol. 8). https://doi.org/10.1016/0169-5150(93)90040-J

10 Dornbusch, R. (1992). The Case for Trade Liberalization in Developing Countries. In Journal of Economic Pers pectives (Vol. 6). https://doi.org/10.1257/jep.6.1.69 
institutions ${ }^{11}$.Smilarly (W acziarg \& Welch, 2008) stated that liberalization raised the average trade to GDP ratio by roughly 5 percentage points, suggesting that trade policy liberalization did indeed raise the actual level of openness of liberalizers. Similarly Atici(2005) stated that liberalization is assumed to bring greater efficiency in to world markets, as asserted by trade theories. As policies are liberalized, factors of production, namely labour and capital, move to more efficient sectors and increase production in those sectors

The high-performing Asian economies have provided the main referencepoint for the resurgence of claims about trade liberalization. The economies of Japan; the Republic of Korea; Taiwan Province of China; Singapore; Hong Kong Special Adminis trative Region, China; Malaysia; Ind onesia; and Thailand have recorded some of the highest GDP growth rates in the world - averaging approximately 6 per cent per annum from 1965 until 1990 - and also some of the highest rates of export growth, averaging more than 10 per cent per annum. Thus, quite often, their s pectacular economic success has been linked to exports or outward orientation, notwithstanding the 1997-1998 economic crises in East Asia.12 However, this success has hardly been based on free trade or laissez-faire. For example, the Governments of Japan and the Republic of Koreahave been highly interventionist, pursuing export promo- tion on the basis of import substitution ${ }^{13}$. The World Bank (1993) has acknowledged that what is important for growth is not whether the free market rules or the Government intervenes, but rather getting the fundamentals for growth right, including government control of financial markets in order to lower the cost of capital, and policies to promote exports and protect domestic industry ${ }^{14}$.

\section{IMPORTANCE OF TARDE LIBERALIZATION}

Developing Countries like Ethiopia are hoping that the reducing or eliminating of restrictions on imports of machines and technological knowledge will allow their enterprises to familiarize newer and better quality machines, machine tools and technological know-how, and that the move to pro-competition policies will produce the pressures and inducements for these changes.

Free trade leads to a more economically rational market structure. Gains from liberalization als o result from scale economies and economies of scope that aris ein wider markets. Moreover, markets in protected economies are narrow and lack of competitors from the rest of the world fosters oligopoly and inefficiency ${ }^{15}$.

The new Ethiopian People's Revolutionary Democratic Front (EPRDF) regime res ponded to the dis mal economic outcome of the Derg era by embarking on an extensive economic liberalization process in 1992/93. It did so with the support of the international fin ancial ins titutions and promising a new era of market-driven development. The key elements of the reform program included liberalization of foreign trade and exchange regimes, decontrol of domestic input and output prices, public sector reform to give autonomy of the state owned enterprises (SOEs) and privatization of some enterprises, financial market reformand opening the door to foreign investors ${ }^{16}$.

Meas uring the benefits of trade reformhas been a frustrating endeavor. Although the dis cussion of trade policy at times gives the impres sion that a liberal trade regime can do wonders for a country's economy, and mos tobservers believe firmly that trade reform is beneficial, yet systematic attempts at quantification fail to single out trade policy as a major factor in economic growth. But then, of course, growth accounting has not come up with a satisfactory explanation for the residual which may be as much as 30 to 50 percent of growth. The channels through which trade liberalizat ion could bring benefits are broadly these: improved resource allocation in line with social marginal cos ts and benefits; access to better technologies, inputs and intermediate goods; an economy better able to take advantage of economies of scale and scope; greater domes tic competition; av ailability of favorable growth externalities, like the transfer of know-how; and a shakeup of industry that may create a Schumpeterian environment especially conducive to growth. This section will comment on each of these factors ${ }^{17}$.

While improvements in trade policies, trade facilitation and the ins titutions that are in the trade sector will serve the goal of greater integration with the world economy they are necessary but not sufficient. After all, Ethiopia needs higher

11. Vi, C. (2002). Economic liberalization and poverty reduction.

12. Brahmbhatt and Dadush (1996) found that, among 93 developing countries studied, the rapidly growing East Asian exporting countries were integrating fastest into the global economy, while low-income countries of sub-Saharan Africa and some middle-income countries in Latin America were integrating less or more slowly.

13. Calvo, G.A., "On the costs of Temporary Liberalization/StabilizationExperiments", in M. Connolly and C. Gonzalez (eds.). Economic Reformand Stabilization in Latin America, Praeger, New York City, New York, 1987.

14. Vi, C. (2002). Economic liberalization and poverty reduction.

${ }^{15}$. Dornbusch, R. (1992). The Case for Trade Liberalization in Developing Countries. In Journal of Economic Pers pectives (Vol. 6). https://doi.org/10.1257/jep.6.1.69

${ }^{16}$ Kurilla, I. (2011). Trade and Transformation, 1832-1850. PONARS Eurasia, 2(July).

${ }^{17}$ Dornbusch, R. (1992). The Case for Trade Liberalization in Developing Countries. In Journal of Economic Perspectives (Vol. 6). https://doi.org/10.1257/jep.6.1.69 
levels of inves tment and savings to reach a higher growth path than the 5\% GDP foreign rate achieved in the recent years (Kurilla, 2011). Trade liberaliza- tion increases the variety of goods, and raises productivity by providing less expensive or higher quality intermediate goods. This as pect has been explored in some recent models of growth; for example, Romer (1989) emphasizes both the productivity of s pecialized res ources and the limitations given by the size of the market. In a res tricted economy, only a narrow range of specialized intermediate goods or capital goods can be profitably produced and therefore the full range of technological possibilities, which rely on a potentially broader range of inputs, cannot be exploited effectively. In this model, a greater variety of in puts does more for production than a greater quantity of a narrow range of inputs. Thus, access to a variety of foreign inputs at a lower cost shifts the economy-wide production function outward, which illus trates a concrete link between productivity and the trade regime ${ }^{18}$

Free trade leads to a more economically rational market structure. Gains from liberalization also result from scale economies and economies of scope that arise in wider markets. Moreover, markets in protected economies are narrow and lack of competitors from the rest of the world fosters oligopoly and inefficiency. Protectionism can create market power for domestic firms, where under free trade there would be none. The casual evidence of these effects is striking. For example, when Mexico liberalized, firms put under pressure by import competition rationalized their activities to the point that they became export competitive. In fact, they looked to export markets to achieve a scale that would allow them to be competitive. Particularly in small countries where imports are restricted, quality is exceptionally low and variety falls far short of what is available in the world market. And prices are, of course, far above the world market, the more so the smaller and more protected the countr ${ }^{19}$.

Higher growth in the last half-decade is believed to haveraised incomes and reduced poverty levels in some [Sub Saharan Africa] countries. However, growth based on resource extraction has also contributed to rising inequality and limited its employment effects, thereby dampening the impact on poverty reduction. In some cases, the combination of slower growth, rising inequalities and vulnerability to exogenous shocks has contributed to civil conflict, further trapping these countries in a vicious spiral of economic decline (Miguel, Satyanath and Sergenti, 2004) as cited in (Jomo \& Von Arnim, 2012).

Ethiopia can benefit as other developing countries have done in the last five decades from greater integration into the world trading system. By making the country more tradable through the remov al of present barriers to trade- behind the border, at the border and beyond in importing countries, Ethiopia can avail itself to additional opportunities to raise growth and reduce poverty. To avoid the vicis situdes of adverse terms of trade shocks, Ethio pia has to diversify its export base in a manner to foster efficiency. Trade diversification can only be accomplis hed in the context of growing exports, given the small size of the domestic market. Growth in trade raises national income and helps to addres s poverty more effectively than a mere distribution of income from a slow income growth. A simple es timate shows that if income were to be dis tributed uniformly at the current level of per capita income $\$ 100$ everyone will be below the internationally excepted poverty level of one dollar a day ${ }^{20}$.

\section{THE NATURE OF TRADE LIBERALIZATIONS}

In contrast to the slow and uncoordinated liberalization steps of the so called 'Mixed Economic Policy' in 1990, an abrupt and quick move towards liberalization has been taken by the TGE. By way of introduction some of the major policy reforms undertaken since October 1992 are reviwed in this section very briefly s o as to get ins ight into the nature and type of liberalization that the country has undergone. These are: The devaluation of the currency from 2.07 birr to 5 birr per US dollar as of October. 1992 and this is supposedly intended to correct the foreign exchange disequilibria. Effective October, 1992, interest rate ceilings have been adjusted upwards in order to realize positive real interest rates, and eliminate differentials among types of ownership. Sector differences in lending rates were als o narrowed but not fully eliminated in order to guide the banks on relativerisks. As of December, 1992 taxes and duties on exports (except coffee) were abolished. Direct subsidy to exports were also eliminated. The regulation governing franco-valuta trade was further liberalized since January, 1992. Specifically, a special franco-valu ta permit is no longer required for most imports, such as personal effect, and goods used to carry out an importer's licensed activities.

In a move to liberalize the exchange market, the Governmentintroduced on May 1, 1993 a foreign exchange auction. The auction is managed by the NBEand is en visaged to take place on a hi-weekly basis. In the system, each successful bidder pays the price of which he bid, until the supply of foreign exchange is exhausted. The marginal rate(the lowest rate) established

\footnotetext{
${ }^{18}$ Dornbusch, R. (1992). The Cas e for Trade Liberalization in Developing Countries. In Journal of Economic Pers pectives (Vol. 6). https://doi.org/10.1257/jep.6.1.69

${ }^{19}$ Dornbusch, R. (1992). The Case for Trade Liberalization in Developing Countries. In Journal of Economic Pers pectives (Vol. 6). https://doi.org/10.1257/jep.6.1.69

${ }^{20}$ Kurilla, I. (2011). Trade and Transformation, 1832-1850. PONARS Eurasia, 2(July).
} 
at the auction is deemed the secondary rate and is applied to all current and capital account transactions until the next auction, with the exception of a limited number of payments for which foreign exchange is made available at the official rate.

The new In vestment Code redefined the position of foreign investors. The Proclamation guarantees the right of foreign investors to remit their profits and dividends and to pay related fees, royalties, and other foreign exchange costs. However, the Code reserves certain sectors, including most of the fin ancial, energy, and rail/air transportation sector, for in vestment by the government. A harmonized system of import tariff rescheduling means to narrow the gap between tariff rates applicable to different commodities, and to reduce the level of import tariff rates applicable to durable consumer items has been placed in force on August 16, 1993.

An export trade duty incentives scheme which encourages domestic production of exports through duty draw-backs and duty free importation scheme for raw material imports, exclu sively used for that purpose, has been effected as of August 18, 1993. In implementing these measures the government's goal is to improve the economic condition through market forces. In other words, it is intended to bring about a market structure in the country's economy and thereby promote economic development.

Obviously, the next question would be "Is the ongoing trade liberalization leading to success or failure?."The answer to this question demands a full-fledged analysis of empirical data, which is lacking at the moment. A brief glimpse into some of the basic economic indicators like prices, exchange rates. interest rates and so on is however, in order to indicate the wholesome trend.

Before going through these variables, however, it is worth having a brief look into the theoretical debate on the timing and sequencing of liberalization, which would possibly lay the $\bullet$ ground for identifying to what line of thinking the country's reform measures belong and what the next steps should be for the success of the reform programme. Broadly categorizing, there are two schools of thought that debate on the problems of "liberalization first" and "stabilization first". In what order should different markets be liberalized? Should a country tackle the inflationary problembefore dealing with market-oriented reforms, or the vice versa? How costly is to undertake liberalization reforms while the labor market is still regulated and dis torted?

A mong those who favour "liberalization first" strategy or the simultaneous implementation of both policies are Krueger (1984), and Corden (1987). They argue that there is little connection between disinflation and liberalization policies, and that the costs of trade restrictions are too high to ju stify the postponement of liberalization until the macro-economy has regained equilibrium. They are particular in pointing out, however, that in order to ensure the success of the trade reform, it is necessary to avoid real exchange rate overvaluation.

On the other end are those who support the "stabilization first" sequence, the proponents of which include Mckinnon (1984), and Fis her(1987). They base their arg ument on a number of considerations, including overvaluation in countries with high fis cal deficit, and the relation between inflation, relative price variability, and resource allocation. It is therefore suggested that correcting the macro-economic dis equilibria should take precedence. Moreover, according to those economists who advocate the 'stabilization first' strategy, it is a step-wise move, not to open the capital account prior to ensuring that the distressed industries are well on their feet; the private sector is well oriented to the market system: and the foreign exchange earning capacity of the country is improved. Otherwise, reversal of the reform would be the case as the real exchange rate would start to appreciate. To this end, Calvo (1987) explains that if a trade reform lacks credibility due to macro-economic instability, the public will use foreign funds that have been made available through the liberalization of the capital account to import larger amounts of goods, especially durable, than otherwise. This "over-importation" will res ult in welfare losses. Since under these circums tances the liberalization of capital account magnifies the pre-exis ting distortions, (i.e., taxes or tariffs). Calvo recommends that in countries where governments lack credibility, capital account controls should not be removed until the trade liberalization programis fully consolidated. Thus from this credibility vantage it is that capital account controls should not be lifted in the early s tage of the structural adjustment program. In light of the above arguments, therefore, the 1992 reform programme of Ethiopia may be put more or less in the latter group i.e., "stabilization first" strategy.

\subsection{The Real Interest Rates}

The real rate of interest' had been increasingly negative for a couple of years, preceding the adjustment program as a result of mounting inflation. It is only in the years $1986 / 87$ and $1987 / 88$ that the rate was positive and this was because inflation went down to the level of -9.5 and 2.2 percent respectively (see Table 1 again). This means that Ethiopiaturned froma strongly positive to severely negative real interest rate, as a result of which the country was classified among the highly repressed economies'. 
Table 1: The Real Interest Rates before the October, 1992 Adjustment (in percent)

\begin{tabular}{|l|l|l|l|}
\hline Year & Nominal Rates* & Inflation Rates & Real Interest Rate \\
\hline $1986 / 87$ & 6.35 & -9.5 & 17.7 \\
\hline $1987 / 88$ & 6.70 & 2.2 & 4.5 \\
\hline $1988 / 89$ & 6.70 & 9.6 & -2.6 \\
\hline $1989 / 90$ & 2.43 & 5.2 & -2.6 \\
\hline $1990 / 91$ & 1.00 & 20.9 & -16.4 \\
\hline $1991 / 92$ & 3.63 & 21.0 & -14.3 \\
\hline
\end{tabular}

* According to IMF definition of deposit rates. This is the rate offered by Commercial Bank of Ethiopia on twelve-month time deposits.

Nominal interest rates have been rais ed since October, 1992, in line with the on-going s tructural adjustment program The lower deposit rate of 3.63 percent was raised to 10 percent. Consequently, the real rate became positive for the last two quarters of 1992/93 fis cal year (see Table 1). As could be seen from the table below, the real rate of interest' registered a meagre negative of -0.5 percent in the second quarter of $1992 / 93$, only to go up to 0.5 percent in the third quarter as inflation dropped to 9.4 percent. In the fourth quarter, however, as inflation went up slightly to 10 percent, the real rate declined to zero (break-even point). As a result, the real rate of interest for long-term deposits werekept positive all through the quarters. Thus, the stability in the general prices recorded through the quarters would imply that the likely threat of over-liquidity problem that could arise from poor res ponse of private investors to a further increase in bank lending rates is moderated. Furthermore, the prospect seems encouraging for private investment to expand in the face of excess demand for goods and services in the market. The real financial assets also grew tremendously in 1993 compared to their level in the previousyears, indicating an improvement in the country's financial situation. Such growing real financial assets would accelerate the country's economic growth and private investment.

Table 2 : Real interest Rates after the October, 1992 Nominal Interest Rate Adjustment (Percentage change)

\begin{tabular}{|c|c|r|r|c|}
\hline & & & Nominal & $\begin{array}{c}\text { Real Interest } \\
\text { Rates }\end{array}$ \\
\hline In the II quarter of 1992/93 & 849.0 & 10.5 & $10 \%$ & -0.5 \\
\hline In the 111 quarter of 1992/93 & 834.1 & 9.4 & $10 \%$ & $0.5 \%$ \\
\hline In the IV quarter of 1992/93 & 849.0 & $10.0 \%$ & $10 \%$ & $0.0 \%$ \\
\hline
\end{tabular}

* Annualized Average

Table 3: Growth Rates of Financial Assets and GDP 1990/91-1992/93

\begin{tabular}{|c|r|r|}
\hline Year & $\begin{array}{c}\text { Real Financial } \\
\text { as sets }\end{array}$ & Real GDP $^{2}$ \\
\hline $1990 / 1$ & $-1: 9$ & -0.3 \\
\hline $1991 / 2$ & -6.4 & -10.0 \\
\hline $1992 / 3$ & $6_{-}^{\prime}$ & $9.2^{\prime}$ \\
\hline
\end{tabular}

Source: National Bank of Ethiopia.

1. Broad Money $\left(\mathbf{M}_{2}\right)$ deflated by the consumer's price index

2. Gros s Domestic Product at 1980/81 constant factor cost. Projected 


\section{Trends in private sector exports after the reforms}

The priv ate sector in general and its participation in export in particular had been significantly undermined under the previous military government, whose development strategy was socialisation of the economy. The sector is now, being accorded due recognition as the main source of the country's foreign exchange earnings, and is seen as the pace-setter for growth.

\section{IMPACT OF THE REFORM: INFLATION, THE REAL EXCHANGE RATE AND REAL RATE OF INTEREST}

The basic macro-econ omic in dicators like prices, the real exchange rate and the real interest rate have shown tremendous improvements in the period between October, 1992 and June, 1993.

\subsection{Inflation}

Inflation which started to mount to a higher level in 1990/91 and 1991/92 declined tremendously in 1992/93 despite the decline in real GDP. It is not, however, true to attribute such a decline solely to the reform. There were also external factors which contributed to this decline. Below, the important factors which affected the level of prices are discussed in brief.

To begin with, the 1990/91 civil war pushed up prices to unexpected level due to the disruption of agricultural production in cereal producing areas, blockade of roads leading to the central market (i.e., Addis Ababa for which the price index is computed). This would be clear if one looks at the data compiled in Greg orian than Ethiopian Calendar (compare Table 1 below with Annex 1). The general price rose to 35.7 percent in 1991 from that of 5.1 percent in 1990. The biggest price increase was recorded, especially in the months between January and June which was around 27 percent. The end of the war and the restoration of political s tability in the major parts of the country, therefore, caused prices to decline. As such, prices are affected basically by the variables operating under normal circumstances.

Table 4

\begin{tabular}{|c|c|c|c|c|c|c|c|c|}
\hline \multirow[t]{2}{*}{ Year } & \multirow[t]{2}{*}{1989} & \multirow[t]{2}{*}{1990} & \multirow[t]{2}{*}{1991} & \multirow[t]{2}{*}{1992} & \multicolumn{4}{|c|}{1992} \\
\hline & & & & & I & 11 & III & IV \\
\hline Inflation rates & 7.8 & 5.1 & 35.7 & 10.5 & 1.5 & 5.1 & 5.1 & 0.6 \\
\hline
\end{tabular}

Source: National Bank of Ethiopia

It is obvious from the table that the level of inflation registered in 1992 was only 10.5 percent. When we look at the quarterly computed indices, however, prices were relatively s table even before the October 1992 basic reform. Secondly, the lion's share of consumer goods were imported either through black market or franco-valuta, whose prices are obviously quoted at the parallel market level. Moreover, most of the public enterprises were operating below capacity due to shortage of foreign exchange. The increased utilization of industrial capacity would therefore reduce the impact of devaluation through the reduced level of per unit production costs. Thirdly, the increased inflow of foreign currencies through IMF and World Bank has a lot to do in tackling the problemof inflationary financing of the budget deficit through domestic bank borrowing.

\subsection{The Real Exchange Rate}

In the exchange rate area, the real exchange rate has shown relative stability (See Table2). The gap between the official and parallel market exchange rate remained relatively small and stable after devaluation. A number of factors are responsible for this outcome. The government's wis e action on tariff rates applicable on imports is worth mentioning. Had the tariff rates been adjusted downwards before or immediately after devalu ation, the demand for imports would have shot up. Consequently, the real exchange rate would have appreciated.

As we see from the table the real exchange rate' first depreciated slightly favoring exporters and then started to appreciate but not significantly. Though the time frame short for analysis of the stability of the real exchange rate, as most economists agree, it is a sign of success in the liberalization effort. For instance, Carbo and de Melo (1987) had evaluated the experience of countries in the so-called Southern Cone (Argentina, Chile, Uruguay) with liberalization policie! in the early 1980s. They pointed out that the behavior of the real exchange rate and more specifically the persistent real exchange rate overvaluation that developed in all three nations waf one of the main causes of the unfavourable outcome of those reforms. 
More recently, Edwards (1989) has shown that real exchange rate behavior is at the heart of the issue of why only a handful of the countries that have received World Bank structural Adjustment Loans (SALs) have succeeded in liberalizing their economies.

Table 5

The RealExchange Rate In dices after October, 1992

\begin{tabular}{|l|l|l|l|}
\hline Quarters & 1992 & 1993 \\
\hline & IV & I & 11 \\
\hline RealExchange Rates Indices & 1.00 & 0.98 & 1.04 \\
\hline
\end{tabular}

The introduction of the auction systemin April, 1993 is one step forward towards a market-determined exchange rate. This system is not without its own limitations, however. There is a possibility at some point that bidders may forminformal collusion to determine the auction rate to their own interest, which would be detrimental to the development of foreign exchange markets. The on-going liberalization program, among other things, is intended to bring about a dynamic change in the involvement of private businessmen in exports. Devaluation of the birr, elimination of all export taxes except that on coffee, duty-draw backs and duty free importation of raw materials are among the major policy reforms undertaken in promote the export sector.

As briefly discussed in the previous sections, the reformh as brought about economic stability at least over the period covered in this analysis. More specifically, inflation has gone down significantly; the real exchange rate and the real interest rate have become stable; and the gap between the parallel and official exchange rate is closing. These are positive economic signals thatencourage private investment especially in the area of exports and, moreover, divert illegal exports into the official channel. In the short-run, however, only the effects on the latter are relatively more significant. For private investors to take investment ris ks, the country should be able to secure a relatively longer period of economic stability and in vestment barriers must be removed.

In the next few paragraphs the paper will try to look into the short-run effects of the reform on private export development. For comparison purpose the data is measured in quantum. Table 6 depicts that private exports have shown significant improvement since liberalization. In 1992193 exports of coffeeby private exporters increased to 15,946 tons from its level of 7,934 tons in 1991/92, registering a 101 percent growth. And this is even higher than those attained in 1989/90 and $1990 / 91$. With respect to oilseeds and pulses also private, exports grewby 683 percent. 'Chat' export grew by 947 percent and spices by 45.1 percent. Whereas, export of Meat and Meat products registered a fall of 93.3 percent. This is due to the rising prices for cattle, whose upward trend is explained by increased competition fromneighboring countries.

Table 6

Major Exports of the Priv ate Sector 1989/90-1992/93

(In tons)

\begin{tabular}{|l|l|l|l|l|}
\hline Type & $1989 / 90$ & $1990 / 91$ & $1991 / 92$ & $1992 / 93$ \\
\hline Coffee & 10,768 & 8,641 & 7,934 & 15,946 \\
\hline Meat and Meatprod. & - & & 60 & 4 \\
\hline $\begin{array}{l}\text { Oilseeds and pulses } \\
\text { Fruits and vegetables }\end{array}$ & 7,702 & 4,130 & 271 & 2,122 \\
\hline Chat & 11.769 & 11,821 & 7,767 & 13,397 \\
\hline Spices & 2,741 & 1,781 & 268 & 2,806 \\
\hline
\end{tabular}

Source: Ministry of Trade. Annual Reports

The major s ource of increase in private exports is obviously the diversion of illegal exports into the official channel and reduction in domestic consumption. Since most of the exports are agricultural products, one has to wait at least for a few years or two in order to see the effects of the reform. At this point, however, one can safely conclude that the relative s tability of the economy, especially with respect to prices and real exchange rates has helped exporters to export more. But a lot remains to be done in the area of exports and imports for investors to build confidence. 


\section{CONCLUSION}

Despite the short period of time considered for analysis, the liberalization process has been showing some signs of success in the area of exports. The stability in domestic prices which resulted from both internal and external factors should not lead policy makers to the wrong conclusion that they have finished the task of formulating stabilization tools. This is so because. so far, it was the external factors rather than the internal ones that were playing the leading role in determining domestic prices.

The real exchange rate, which is central to the reform, seemed stable for the last three quarters since devaluation revealing that private investors, at least in the short-run, were able to build confidence. The government, however, should continue to man age the exchange rate through auction by augmenting allocated of foreign currencies until the country is able to generate sufficient amount of foreign currency. Otherwise, the real exchange rate might start to appreciate due to the increased demand for imports which can possibly frustrate the reformprogram.

Interest rates and other financial indicators showed improved levels as well. The real rate of interest which showed a positive level after the reform may mean that the economy is in a position to mobilize sufficient amount of investible funds from the public. This is, in fact, without affecting the viability of the financial sector since in vestors are also encouraged by the stable domestic price situation and depreciating real exch angerate.

In addition, the increased availability of foreign exchange through the official channel and the liberalization of francovalutaimports helped producers to increase the level of capacity utilization.

To sum up, the country's step wise liberalization process has shown some favourable prospects for investment and growth. However, the next steps, liberalizing the capital account and leaving the exchange rate to be determined in the market, among other things, require a skillfull design. The capital account which is still left unliberalized has to wait for some time till the economy ensures a sustainablecapacity of generating foreign currencies. Otherwise economic in stability would follow and consequently, the reformprocess would be as stake.

\section{REFERENCES}

- Atici, C. (2005). Liberalization-goals trade-offs. Implications of agricultural trade liberalization for developing countries. In Outlook on Agriculture (Vol. 34). https ://doi.org/10.5367/0000000054224364

- Brandaõ, A. S.P., \& Martin, W. J. (1993). Implications of agricultural trade liberalization for the developing countries. In Agricultural Economics (Vol. 8). https ://doi.org/10.1016/0169-5150(93)90040-J

- Calvo, D. F.. "Argentina:Trade Reform, 1976-1982", in Shephered and Langonied (eds.), Trade Reform: Les sons FromEight Countries, International Center for Economic Growth Publication, California, 1991, PP. 27 40.

- Calvo, G.A., "On the costs of Temporary Liberalization/StabilizationExperiments", in M. Connolly and C. Gonzalez (eds.). Economic Reform and Stabilization in Latin America, Praeger, New York City, New York, 1987.

- Carbo and Jaime de Melo, "Liberalization and Stabilization in the Southern Can e of Latin America: Overview and summary", W orld Development 13, August 1985, PP. 5-15.

- Cordell, W. Max, "Protection and Liberalization: A Review of Analy tical Issues," IMF OccasionalPaper No. 54, International Monetary Fund, Washington D.C., 1987.

- Dornbusch, R. (1992). The Case for Trade Liberalization in Developing Countries. In JournalofEconomic Perspectives (Vol. 6). https://doi.org/10.1257/jep.6.1.69

- Edwards, S., "Stabilization with Liberalization: An Evaluation of Ten Years of Chile's Experience with Free Market Policies", Economic Development and CulturalChange, No. 33, January 1985.

- Fisher, "Economic Growth and Economic Policy", in V. Carbo, et al. (eds.), Growth Oriented Adjustment Programs, IMF-World Bank, Vashington D.C., 1987.

- Hachette. D., "Chile: Trade liberalization since 1974", Opcit, pp. 41-54.

- Jomo, K. S., \& Von Arnim, R. (2012). Economic Liberalization and Constraints to Development in Sub -Saharan Africa. Good Growth and Governance in Africa: Rethinking Development Strategies, (67). https://doi.org/10.1093/acprof:oso/9780199698561.003.0017

- Katrak, H. (2000). Economic liberalization and the vintages of machinery imports in developing countries: An empirical test for India's imports from the United Kingdom. In Oxford Development Studies (Vol. 28). https://doi.org/10.1080/713688317

- Kruger, A.. Foreign Trade Regimes and Economic Development: Liberalization Attempts and Consequences, National Bureau of Economic Res earch. New York City, 1978.

- Kruger. A. 0.. "Problems of Liberalization". in A. Harbergered, World Economic Growth, ICS Press . San Fraties is co, California, 1984, 
- Kurilla, I. (2011). Trade and Transformation, 1832-1850. PONARS Eurasia, 2(July).

- Mackinnon, R. E., The International Capital Market and Economic Liberalization in LDCsn. The Developing Economies, No. 22, December 1984, PP. 476-481.

- Minis try of Trade, Export Promotion in Industry (Addis Ababa) 1989(Amharic Version).

- $\quad$ ONCCP, The First Five Years (1990-94) and The 1990 Annual Development Plan, Addis Ababa Vol. 1 (Amharic Version)p. 53.

- The Order of Economic Liberalization, Financial Control in the Transition to a Market Economy, Johns Hopkin University Press, London, 1991.

- Matambalya, F., \& Wolf, S. (2001). Economic Liberalis ation and Employment in South Asia ZEF. Development Policy Bonn, (42).

- Simmons, B., Dobbin, F., \& Garrett, G. (2007). Introduction : the diffusion ofliberalization.

- $\quad \mathrm{Vi}, \mathrm{C}$. (2002). Economic liberalization andpoverty reduction.

- Wacziarg, R., \& Welch, K. H. (2008). Trade liberalization and growth: New evidence. World Bank Economic Review, 22(2), 187-231. https://doi.org/10.1093/wber//hn007 